\title{
Harmonization of Granting Land Rights for Investment in Land-Law Perspectives in Indonesia
}

\author{
Fifik Wiryani ${ }^{*}$, Mokhammad Najih $^{2}$, Rizkahana Yuliansari ${ }^{3}$, and Asri Rezki Saputra ${ }^{4}$ \\ ${ }^{1}$ Universitas Muhammadiyah Malang, Malang, Indonesia \\ ${ }^{2}$ Universitas Muhammadiyah Malang, Malang, Indonesia \\ ${ }^{3}$ Universitas Muhammadiyah Malang, Malang, Indonesia \\ ${ }^{4}$ Universitas Muhammadiyah Malang, Malang, Indonesia
}

\begin{abstract}
The government has a central and strategic role in econo mic development based on democratic principles aimed at creating a just and prosperous society as mandated by the Constitution. This paper examines the arrangement of land rights (LR) for investment Activities in Indonesia in the perspective of land Act. This study uses a doctrinal juridical approach. The type of data is secondary data sourced from primary legal materials and secondary legal materials. Data collection is carried out using literature and documents both physically and electronically. The data obtained is then analyzed using content analysis and prescriptive analysis. The findings show that the time period for granting land rights from various investment regulations is arranged inconsistently. The root of the problem of inconsistency is the violation of hierarchical principles in the regulation of the timeframe of CR, BR and UR in Act 5 of 1960 with GR 40 of 1996 which is used as the basis for the regulation of the granting of land for investment. As a result, the application of the principle of lex specialis derogate legi generali in granting land in accordance with the principle of legal certainty is contrary to the principles of justice and benefit. So it is necessary to harmonize the Act, by making changes to GR 40 of 1996 and Act 25 of 2007 to be adjusted to the provisions of the period of land rights stipulated in Act 5 of 1960 which is an umbrella Act in the field of land.
\end{abstract}

\section{Introduction}

The government as the state administrator has a central and strategic role in economic development that aims to realize a just and prosperous society as mandated by the Constitution. National economic development must be based on democratic principles that are able to create the realization of Indonesia's economic and political sovereignty.

Investment is part of the implementation of the national economy to increase national economic growth. Investment implementation, especially foreign investment theoretically

\footnotetext{
* Corresponding author: fwiryani2016@gmail.com
} 
can be seen from classic theory and dependency theory. Classic theory sees investment can benefit the recipient countries. On the contrary, according to the dependency theory, the existence of investment only carries the consumptive nature and dependency for developing countries as recipients of investment [1].

Investment policies have existed since Indonesia's independence, namely the enactment of Act 78 of 1958 concerning Foreign Investment (FI) [2], Act 1 of 1967 concerning FI [3] and Act 6 of 1968 concerning Domestic Investment (DI) [4] and Act 25 of 2007 concerning Investment[5].

The implementation of the investment regulation was foreign investment during the New Order period (1967-1997) amounting to 190,631.7 billion US \$ to finance 5,699 projects and during the Reformation period (1998-2006), a total of 117.87 billion US \$ to finance 10,686 projects [6].

During the Old Order, Indonesia's economic conditions were very unequal, namely the Dutch and foreigners controlled international trade, industry and mining using machinery, high-quality large-scale export plantations, transportation businesses other than fire and telecommunications. Whereas the Indonesian people only try in the home industry, smallholder mining, low quality small plantations [2]. These conditions are considered by the government in attracting foreign investors in Indonesia to realize the acceleration and Act 5 of 1960 ance of the economy and increase national production to improve the level of life of the people.

In 1965, the President conveyed the Political Mandate on Stir Slings to Stand on His Own Feet in the Field of Economics and Development. The President's mandate was then followed up by the MPRS-RI by stipulating the MPRS-RI Decree Number VI / MPRS / 1965 concerning Stir Bulls to Stand on Their Own Feet in the Field of Economics and Development, because FDI is a mechanism to exploit the country's wealth and carry out human exploitation of humans, thus bringing disaster for the Indonesian people [7]. Finally, the President enacted Act 16 of 1965 concerning Revocation of Act 78 of 1958.

The economic condition of the New Order was marked by the economic downturn and the purchasing power of the people as well as the economic gap caused by mismanagement, waste, bureaucracy, corruption, G.30.S./PKI rebellion and fraud in the 1945 Constitution. These conditions resulted in the suffering of the people. Efforts to overcome this problem, issued Decree of the Republic of Indonesia MPRS No. XXIII/MPRS/1966 concerning the Renewal of the Policy on the Foundation of Economy, Finance and Development, which mandates the government to prioritize people's economic development based on rational and realistic economic principles. But because of the difficulties of capital and sources of development financing, the government has enacted Act 1 of 1967 and Act 6 of 1968 of PMDN, based on the principle that all efforts must be based on the ability and capability of the Indonesian people themselves by utilizing the potential capital, technology and skills available from abroad, which does not result in dependence on foreign countries [8].

During the reform period, the Government established Act 25 of 2007, which was the realization of the realization of public welfare as mandated by Article 33 of the 1945 Constitution of the Republic of Indonesia and the Decree of the People's Consultative Assembly No. XVI / MPR / 1998 concerning Economic Politics in the Context of Economic Democracy, and for the development of investment for micro, small, medium and cooperative businesses, which are part of the basic policy of investment. Consideration of the enactment of the Act because investment must be part of the implementation of the national economy with the aim of increasing national economic growth, creating jobs, enhancing sustainable economic development, increasing national technology capacity and 
capability, encouraging popular economic development, and realizing public welfare in an economic system who are competitive [5]. Based on consideration of the stipulation of the Investment Act, it appears that the Old Order adhered to dependency theory, while the New Order and the Reformation period adopted the Classic Theory.

In the era of globalization, trade and investment are essential things that are complementary and inseparable [9]. Since the signing of the WTO, developed countries expanded and developed investment in developing countries [9]. The consideration of investors in investing in principle is that there is a guarantee of certainty in business, namely: natural resources, human resources, political and economic stability, government regulations policies, and licensing. In order to attract these investors, all investment regulations both during the Old Order, the New Order and the Reformation, regulated the policy of providing facilities and facilities for investors.

The most vital facility given to investors is the granting of land, because land is an asset that is definitely needed in investment activities [11]. Besides that, land is also a production factor that produces trade commodities.

\section{Objecttive}

This paper examines the arrangement of land administration in investment activities in investment regulations in the perspective of land Act in Indonesia.

\section{Methodology}

This study uses a doctrinal juridical approach. The type of data is secondary data sourced from primary legal materials and secondary legal materials. Data collection is done using library search and documents both physically and electronically. The data obtained is then analyzed using content and prescriptive analysis.

\section{Discussion}

This section discusses the regulation of facilities for investment and the regulation of land provision in investment activities in the investment regulations that had been applied in Indonesia during the Old Order, New Order and Reformation.

\subsection{Granting of Land for Investment Activities Perspective Land Regulations in Indonesia}

Land for the Indonesian people as the main natural resource that has an inner value that functions strategically in meeting the needs of the community [12]. Land has unique characteristics that are multidimensional, multi-disciplinary, multi-sectoral with high complexity [13]. In addition, the land is the infrastructure and an important instrument in fostering economic growth in Indonesia, including in support of investment Activity [14] and [15].

Land regulatory reform in Indonesia began with the enactment of Act 5 of 1960 concerning Basic Agrarian Law which is a form of the implementation of Article 33 of the 1945 Constitution. The Act 5 of 1960 is a legal umbrella of all Acts and regulations governing land. Land Act in the Act 5 of 1960 is largely based on customary Act.

The granting of land rights for investment is regulated in Acts 5 of 1960, Government Regulations 40 of 1996 (GR 40 of 1996), Act 78 of 1958, Act 1 of 1967 and Act 25 of 2007. 
Rights to land granted for investment purposes covering business use rights, rights to use buildings or rights to use. The main problem in granting the land is the different time period between the regulations. The difference in the time period for granting land rights is correlated with the state's efforts to create a just and prosperous society for all Indonesians. In addition, it also provides legal certainty for investors. As for setting the time period for granting land rights for investment, as presented in table 1 below:

\begin{tabular}{|c|c|c|c|c|c|c|}
\hline \multirow[b]{2}{*}{$\begin{array}{c}\text { LAND } \\
\text { RIGHTS }\end{array}$} & \multirow[b]{2}{*}{$\begin{array}{c}\text { TIME } \\
\text { PERIOD }\end{array}$} & \multicolumn{5}{|c|}{ REGULATIONS } \\
\hline & & $\begin{array}{l}\text { Act } 5 \text { of } \\
1960[16]\end{array}$ & $\begin{array}{l}\text { GR } 40 \text { of } \\
1996[17]\end{array}$ & $\begin{array}{c}\text { Act } 78 \text { of } \\
1958[2]\end{array}$ & $\underset{1967[3]}{\operatorname{Act} 1 \text { of }}$ & $\begin{array}{c}\text { Act } 25 \\
\text { of } \\
2007[5]\end{array}$ \\
\hline \multirow{3}{*}{$\begin{array}{c}\text { Cultivation } \\
\text { Rights } \\
\text { (CR) }\end{array}$} & First gift & $\begin{array}{l}25 / 35 \\
\text { years }\end{array}$ & 35 years & $30 / 40$ years & 25 years & \multirow{3}{*}{$\begin{array}{c}95(=35+ \\
25+35) \\
\text { years }\end{array}$} \\
\hline & Extension & 25 years & 25 years & $\begin{array}{l}\text { certain } \\
\text { periods }\end{array}$ & 25 years & \\
\hline & Renewal & - & 35 years & - & - & \\
\hline \multirow{3}{*}{$\begin{array}{c}\text { Building } \\
\text { Rights } \\
\text { (BR) }\end{array}$} & First gift & 30 years & 30 years & 20 years & 30 years & \multirow{3}{*}{$\begin{array}{c}80(=30+ \\
20+30) \\
\text { years }\end{array}$} \\
\hline & Extension & 20 years & 20 years & $\begin{array}{l}\text { certain } \\
\text { periods }\end{array}$ & 20 years & \\
\hline & Renewal & - & 30 years & - & & \\
\hline \multirow{3}{*}{$\begin{array}{l}\text { Usage } \\
\text { Rights } \\
\text { (UR) }\end{array}$} & First gift & $\begin{array}{l}\text { certain } \\
\text { periods }\end{array}$ & 25 years & 10 years & $\begin{array}{l}\text { certain } \\
\text { periods }\end{array}$ & \multirow{3}{*}{$\begin{array}{c}70(=25+ \\
20+25) \\
\text { years }\end{array}$} \\
\hline & Extension & - & 20 years & - & & \\
\hline & Renewal & - & 25 years & - & & \\
\hline
\end{tabular}

Table 1. Regulation of the Period of Granting the Land Right for Investment

Table 1 shows that land rights for investment can be extended based on the evaluation results of the company. Act 5 of 1960 and Act 1 of 1967 provide an extension within a predetermined period of 25 years for Cultivation Right, and 20 years for Building Rights. Whereas for the provision of Usage Rights, the duration is not specified. The extension of Cultivation Rights and Building Rights according to Act 78 of 1958 are not determined by the time period, and Usage Rights cannot be extended or renewed. CR can only be given to large plantation companies that provide important socio-economic contributions to the welfare of the state and the people.

Regulations in the land sector Act 5 of 1960 and GR 40 of 1996 regulate the time period for land rights inconsistently. Act 5 of 1960 only regulates the initial and renewal. Elucidation of Article 29 of Act 5 of 1960 states "according to the nature and purpose of CR, it is the right to land with limited validity. A period of 25 or 35 years with the possibility of extending by 25 years is considered long enough for the need for the cultivation of long-lived plants. "Explanation of the period of HGU in Article 29, also applies mutatis mutandis to other land rights that are limited in time, namely HGB and Use rights granted for a specified period as stipulated in Article 41 paragraph (2) letter a.

GR 40 of 1996 which is the implementing regulation of Act 5 of 1960, does not change the limitation on the period of granting and extension, but adds to adding the term of land rights which has a limited validity period, through the renewal mechanism provided after the extension period. UUPA does not recognize the rules regarding renewal of land rights. Renewal of rights clearly contradicts the spirit of the Act 5 of 1960 which seeks to limit the 
time of land ownership for investment. This is consistent with the purpose of the enactment of the Act 5 OF 1960, which "laid the foundations for the preparation of the national agrarian law, which would constitute a means to bring prosperity, happiness and justice for the State and the people, especially the farmer, in the framework of a just and prosperous society".

GR 40 of 1996 which is the implementing regulation of Act 5 of 1960, does not change the limitation on the period of granting and extension, but adds to adding the term of land rights which has a limited validity period, through the renewal mechanism provided after the extension period. UUPA does not recognize the rules regarding renewal of land rights. Renewal of rights clearly contradicts the spirit of the Act 5 of 1960 which seeks to limit the time of land ownership for investment. This is consistent with the purpose of the enactment of the Act 5 of 1960, which "laid the foundations for the preparation of the national agrarian law, which would constitute a means to bring prosperity, happiness and justice for the State and the people, especially the farmer, in the framework of a just and prosperous society".

The inconsistency in regulating the time period for granting land rights for investment in Act 5 of 1960 and GR 40 of 1996 resulted in a legal conflict which had implications for legal uncertainty [18]. According to the principle of hierarchy, the GR 40 of 1996 should not conflict with Act 5 of 1960 as a higher regulation on it. So that based on this principle, the provision for granting the time period for the ownership of land rights that must be used as a basis is a provision in Act 5 of 1960, so that the mechanism for renewal of the land rights as stipulated in GR 40 of 1996 does not have a binding capacity.

Provisions regarding the limitation of the term of land rights in Act 5 of 1960 cannot be separated from the provisions for the removal of land rights. Based on the elucidation of article 14 of Act 5 of 1960 relating to the abolition of land rights, then after the expiry of the initial and/or extension of CR, BR and UR by law pursuant to Article 34.a and 40.a, the right is deleted when the term expires.

The period of granting land rights in the legal regime of investment has experienced a progress towards more pro-investors as the will of the WTO which Indonesia has ratified with Act 7 of 1994. The period of granting land rights in Act 78 of 1958 and Act 1 of 1967 the substance refers to the provisions of Act 5 of 1960, namely first gift and extension. Whereas in Act 25 of 2007, referring to GR 40 of 1996, namely the mechanism for granting land rights, extension and renewal. To guarantee legal certainty for investors, the granting, extension and renewal of the right is at the same time granted at the beginning of the granting of their rights.

If Act 5 of 1960 and Act 25 of 2007 are juxtaposed, then Act 5 of 1960 is a generally accepted provision, while Act 25 of 2007 applies specifically to land in the field of investment. Based on the principle of lex specialis derogate legi generali, Act 25 of 2007 has a stronger position than Act 5 of 1960 . So the time period for granting land rights for the applied investment is a provision in Act 25 of 2007. The application of this principle is consistent with the value of certainty law.

However, the implementation of Act 25 of 2007 which provides, extends and renews land rights up to 95 years without prior evaluation, shows excessive protection to investors so that it is contrary to the value of social justice for the Indonesian people as the basis of the philosophy of Pancasila and the mandate of the constitution. As a comparison, Agrarische Wet in the colonial period only gave Erfpacht Rights to Investors in a period of only 75 years.

When examined in the perspective of legal objectives and functions, there is a conflict between the principle of legal certainty and the principles of justice and expediency. The application of the principle of lex specialis derogate legi generali is in accordance with the principle of legal certainty, but deviates from the principles of justice and the principle of 
benefit. Therefore, according to the author, for the benefit of the Indonesian Nation, the principle of "lex specialis" in this case can be deviated and does not need to be applied.

Through Decision Number 21-22 / PUU-V / 2007, the Constitutional Court (MK) has amended Act 25 of 2007 Article 22 paragraph (1) and (2) as far as the words "in advance" and Article 22 (4) as long as the words "at one time in front" do not have the power of binding law. Thus, the provisions for the terms of the CR, BR and UR in Act 25 of 2007 follow the GR 40 of 1996 provisions Article 8, 25 and 45. In the perspective of land law, the decision of the Constitutional Court is inappropriate. Supposedly the period of land rights for investment interests refers to Act 5 of 1960.

\section{Conclusion}

The granting of land rights for investment activities is regulated in all investment regulations in Indonesia. Investors can only be given land rights that have a limited period of time, namely CR, BR and UR. The period of granting land rights from various investment regulations is arranged inconsistently. The root of the problem of inconsistency is the existence of violations of the principle of hierarchy in the timeframe setting of CR, BR and UR in Act 5 of 1960 with GR 40 of 1996 which is used as the basis for regulating the granting of land for investment. As a result, the application of the principle of lex specialis derogate legi generali in granting land in accordance with the principle of legal certainty is contrary to the principles of justice and expediency.

As an effort to fulfill the principles of legal certainty, justice and benefit in regulating the granting of land rights for investment, it is necessary to harmonize the law. Harmonization is carried out by making changes to GR 40 of 1996 and Act 25 of 2007 to be adjusted to the provisions concerning the period of land rights stipulated in Act 5 of 1960 which is an umbrella law in the land sector.

\section{References}

1. E. Sulastri, Salam, Pp. 267-280 (November 2014).

2. F. Dona, Al-Ahkam, 2:1, 79 (2017)

3. Law No. 78 Year 1958

4. Law No. 1 Year 1967

5. Law No. 6 Year 1968

6. Law No. 25 Year 2007

7. M. W. Suradiyanto, DIH J. Ilmu Hukum, 11:21, Pp.25-32 (2015)

8. Majelis Permusyawaratan Rakyat Decree No. VI/MPRS/1965 Year 1965

9. Acep Rohendi, Padjadjaran J. Ilmu Huk., 1:2, Pp. 386-406 (2014).

10. A. S. Hutagalung, Hukum dan Pembangunan, 38:3, Pp. 353-370 (2008).

11. Ilhamdi, Lega Lata, I:2, Pp. 329-348 (2016).

12. Efrimol, Inovatif, 4:5, Pp. 37-51 (2011).

13. A. Weri, KIAT, 8:1, Pp. 32-46 (2016).

14. Suparji, "Pengaturan Tanah Untuk Kegiatan Investasi," Kopertis 3. [Online]. Available: http://portal.kopertis3.or.id/bitstream/123456789/1053/1/Artikel Jurnal Pengaturan Tanah Utk Investasi.pdf. [Accessed: 13-Aug-2018].

15. Law No. 5 Year 1960

16. Government Regulation No. 40 Year 1996.

17. D. Ginting, Jurnal Hukum, 18:1, Pp. 63-82 (2011). 